\title{
Hubungan antara Inovasi Kepala Sekolah, Kelengkapan Sarana Prasarana Sekolah, Motivasi Kerja dengan Kinerja Guru SMA
}

\author{
Ade Safitri \\ Manajemen Pendidikan-Universitas Negeri Malang \\ Jl. Semarang 5 Malang. Email: ade_8828@yahoo.com
}

\begin{abstract}
This research aims to determine the relationship between the headmaster innovation (KS), the completeness of school infrastructure, and motivation to work with teacher performance. This study uses a quantitative approach design. The population of all the State High School teacher in Sumbawa Besar and sampling using proportionally. Analysis of the data using path analysis. The results of this study are: there is a direct relationship between the KS and teacher performance innovation, there is a direct relationship between innovation KS with work motivation of teachers, there is a direct relationship between the completeness of the infrastructure with the performance of teachers, there is a direct relationship between the completeness of the infrastructure work motivation of teachers, there is direct relationship between work motivation with teacher performance, there is a direct relationship between innovation KS, completeness school infrastructure, work motivation, teacher performance, there is no direct relationship between innovation $\mathrm{KS}$, work motivation, teacher performance, there is no direct relationship between the completeness of the facilities school infrastructure, work motivation, with teacher performance.
\end{abstract}

Key Words: innovation, principals, school infrastructure, work motivation, teacher performance

\begin{abstract}
Abstrak: Penelitian ini bertujuan untuk mengetahui hubungan antara inovasi kepala sekolah (KS), kelengkapan sarana prasarana sekolah, dan motivasi kerja dengan kinerja guru. Penelitian ini menggunakan rancangan pendekatan kuantitatif. Populasinya semua guru SMA Negeri di Kabupaten Sumbawa Besar dan pengambilan sampel menggunakan teknik secara proporsional. Analisis data menggunakan analisis jalur. Hasil penelitian ini adalah: terdapat hubungan langsung antara inovasi KS dengan kinerja guru, terdapat hubungan langsung antara inovasi KS dengan motivasi kerja guru, terdapat hubungan langsung antara kelengkapan sarana prasarana dengan kinerja guru, terdapat hubungan langsung antara kelengkapan sarana prasarana dengan motivasi kerja guru, terdapat hubungan langsung antara motivasi kerja dengan kinerja guru, terdapat hubungan langsung antara inovasi KS, kelengkapan sarana prasarana sekolah, motivasi kerja, dengan kinerja guru, terdapat hubungan tidak langsung antara inovasi KS, motivasi kerja, dengan kinerja guru, terdapat hubungan tidak langsung antara kelengkapan sarana prasarana sekolah, motivasi kerja, dengan kinerja guru.
\end{abstract}

Kata kunci: inovasi, kepala sekolah, sarana prasarana sekolah, motivasi kerja, kinerja guru

Perkembangan ilmu pengetahuan dari tahun ke tahun semakin maju dan dapat dilihat dari berbagai aspek. Sekolah merupakan salah satu lembaga pendidikan yang menjadi wadah bagi para peserta didik untuk memperoleh pendidikan. Guru mempunyai peran penting dalam proses pembelajaran dan dalam pencapaian tujuan pembelajaran. Guru merupakan pendidik profesional dengan tugas utama mendidik, mengajar, membimbing, mengarahkan, melatih, menilai, dan mengevaluasi hasil pembelajaran siswa.

Pemegang peran yang sangat penting dalam lembaga pendidikan yaitu kepala sekolah. Kepala sekolah selalu mengikuti perkembangan yang ada selama hal tersebut membawa dampak yang positif dalam perkembangan sekolah sesuai dengan tujuan yang diharapkan. Oleh karena itu, dibutuhkan suatu 
inovasi yang dilakukan oleh kepala sekolah. Menurut Suharsono dan Retnoningsih (2011) dalam Kamus Besar Bahasa Indonesia dinyatakan bahwa inovasi adalah pemasukan atau pengenalan hal-hal yang baru; pembaruan; penemuan baru yang berbeda dari yang sudah ada atau yang sudah dikenal sebelumnya (gagasan, metode, atau alat).

Pelaksanaan kepemimpinan kepala sekolah dapat mengarahkan para bawahannya terutama tenaga pendidik/guru. Guru juga memiliki peran yang sangat penting dalam proses pembelajaran dan tercapainya tujuan pembelajaran. Guru dituntut untuk meningkatkan kualitasnya serta dapat melaksanakan tugasnya sesuai dengan kewajiban dan tanggung jawabnya. Untuk mencapai hal tersebut perlu didukung oleh beberapa faktor penunjang, salah satunya yaitu tersedianya sarana dan prasarana yang memadai. Adanya sarana dan prasarana yang memadai maka kegiatan pembelajaranpun dapat berjalan lancar.

Impian ideal para guru sering kali sulit terealisasi tanpa tersedianya sarana dan prasarana sekolah untuk mengambangkan kreativitasnya, serta bantuan yang diberikan oleh kepala sekolah dalam memfasilitasi, terjalinnya hubungan yang harmonis dengan lingkungan sekolah, mencari dan menemukan gagasan baru, mengintegrasikan kegiatan-kegiatan sekolah, dan mengembangkan pembelajaran yang inovatif. Direktorat Tenaga Kependidikan Direktorat Jenderal Peningkatan Mutu Pendidik dan Tenaga Kependidikan Departemen Pendidikan Nasional Tahun (2007) menyatakan bahwa sarana dan prasarana pendidikan merupakan salah satu sumber daya yang penting dan utama dalam menunjang proses pembelajaran di sekolah, untuk itu perlu dilakukan peningkatan dalam pendayagunaan dan pengelolaannya agar tujuan yang diharapkan dapat tercapai. Dengan adanya sarana dan prasarana, peserta didik maupun guru dapat menjalankan kegiatan pembelajaran dengan lancar dan dapat termotivasi.

Motivasi merupakan proses yang ikut menentukan intensitas, arah, dan ketekunan individu dalam usaha mencapai sasaran (Robbins, 2006). Tingkat pendidikan, motivasi, usia dan pengalaman kerja karyawan baik baru maupun lama merupakan sebagian faktor yang dapat mempengaruhi kinerja dalam rangka mengembangkan dan meningkatkan profesionalitas karyawan dalam pekerjaannya dan menyesuaikan diri dengan perubahan dan pengembangan yang berlangsung sekarang ini.

Guru merupakan komponen yang paling berpengaruh terhadap terciptanya proses dan hasil pendidikan yang berkualitas. Oleh karena itu upaya perbaikan apapun yang dilakukan untuk meningkatkan kualitas pendidikan tidak akan memberikan sumbangan yang signifikan tanpa di dukung oleh guru yang profesional dan berkualitas. Sebagai pengajar atau pendidik guru merupakan salah satu faktor penentu keberhasilan setiap upaya pendidikan. Kinerja guru dalam merencanakan dan melaksanakan pembelajaran, merupakan faktor utama dalam pencapaian tujuan pengajaran, keterampilan peguasaan proses pembelajaran ini sangat erat kaitannya dengan tugas dan tanggung jawab guru sebagai pengajar dan pendidik secara sempit dapat di interprestasikan sebagai pembimbing atau belajar fasilator belajar siswa.

Menurut Mangkunegara (2007) kinerja merupakan hasil kerja secara kualitas dan kuantitas yang dicapai oleh seorang pegawai dalam melaksanakan tugasnya sesuai dengan tanggung jawab yang diberikan kepadanya. Keberhasilan kinerja akan tampak apabila terdapat motivasi kepala sekolah, lingkungan sekitar juga dapat menentukan keberhasilan kinerja seseorang oleh karena itu, selain gurunya sendiri yang berusaha meningkatkan kualitas kerjanya, pihak sekolah juga berusaha mengupayakan pemberdayaan gurunya agar memiliki kinerja yang baik, dan profesional dalam menjalankan tugasnya. Seorang guru yang baik adalah guru yang mampu mewujudkan suasana pembelajaran yang menyenangkan dan membuat peserta didik merasa nyaman menuntut ilmu bersama gurunya.

Dapat disimpulkan bahwa inovasi yang dilakukan oleh kepala sekolah, kelengkapan sarana prasarana sekolah, dan motivasi kerja, sangat ditentukan oleh kinerja guru. Demikian juga keberhasilan pendidikan sebagaian besar ditentukan oleh kinerja guru.

Rumusan hipotesis penelitian adalah: (1) terdapat hubungan langsung yang signifikan antara inovasi kepala sekolah dengan kinerja guru SMA Negeri di Sumbawa Besar, (2) terdapat hubungan langsung yang signifikan antara inovasi kepala sekolah dengan motivasi kerja guru SMA Negeri di Sumbawa Besar, (3) terdapat hubungan langsung yang signifikan antara kelengkapan sarana prasarana sekolah dengan kinerja guru di SMA Negeri di Sumbawa Besar, (4) terdapat hubungan langsung yang signifikan antara kelengkapan sarana prasarana sekolah dengan motivasi kerja guru di SMA Negeri di Sumbawa Besar, (5) terdapat hubungan langsung yang signifikan antara motivasi kerja dengan kinerja guru SMA Negeri di Sumbawa Besar, (6) terdapat hubungan langsung yang signifikan antara inovasi kepala sekolah, kelengkapan sarana prasarana sekolah, motivasi kerja, dengan kinerja guru SMA Negeri di Sumbawa Besar, 
(7) terdapat hubungan tidak langsung yang signifikan antara inovasi kepala sekolah, motivasi kerja, dengan kinerja guru SMA Negeri di Sumbawa Besar, dan (8) terdapat hubungan tidak langsung yang signifikan antara kelengkapan sarana prasarana sekolah, motivasi kerja, dengan kinerja guru di SMA Negeri di Sumbawa Besar.

\section{METODE}

Penelitian ini menggunakan pendekatan kuantitatif. Variabel yang digunakan dalam penelitian adalah variabel bebas yaitu inovasi kepala sekolah $\left(\mathrm{X}_{1}\right)$, kelengkapan sarana prasarana $\left(\mathrm{X}_{2}\right)$, motivasi kerja $\left(\mathrm{X}_{3}\right)$, dan variabel terikat yaitu kinerja guru $(\mathrm{Y})$. Populasi dalam penelitian adalah seluruh guru SMA Negeri di Kabupaten Sumbawa Besar yang berjumlah 210 orang. Teknik pengambilan sampel yang digunakan yaitu proportional sampling. Jumlah sampel dalam penilitian yakni 118 guru. Skala pengukuran yang digunakan dalam penelitian yaitu Skala Likert.

Analisis validitas yaitu menggunakan rumus Korelasi Pearson Product Moment dan reliabilitas menggunakan rumus Alpha Cronbach. Cara mendapatkan data dalam penelitian adalah dengan menggunakan teknik kuesioner (angket). Teknik analisis datanya menggunakan alisis jalur (path analysis).

\section{HASIL}

Hasil penelitian menunjukkan bahwa: (1) terdapat hubungan langsung antara inovasi kepala sekolah dengan kinerja guru SMA Negeri di Kabupaten Sumbawa Besar, (2) terdapat hubungan langsung antara inovasi kepala sekolah dengan motivasi kerja guru SMA Negeri di Kabupaten Sumbawa Besar, (3) terdapat hubungan langsung antara kelengkapan sarana prasarana dengan kinerja guru SMA Negeri di Kabupaten Sumbawa Besar, (4) terdapat hubungan langsung antara kelengkapan sarana prasarana dengan motivasi kerja guru SMA Negeri di Kabupaten Sumbawa Besar, (5) terdapat hubungan langsung antara motivasi kerja dengan kinerja guru SMA Negeri di Kabupaten Sumbawa Besar, (6) terdapat hubungan langsung antara inovasi kepala sekolah, kelengkapan sarana prasarana sekolah, motivasi kerja, dengan kinerja guru SMA Negeri di Kabupaten Sumbawa Besar, (7) terdapat hubungan tidak langsung antara inovasi kepala sekolah, motivasi kerja, dengan kinerja guru SMA Negeri di Kabupaten Sumbawa Besar, (8) terdapat hubungan tidak langsung antara keleng- kapan sarana prasarana sekolah, motivasi kerja, dengan kinerja guru SMA Negeri di Kabupaten Sumbawa Besar.

\section{PEMBAHASAN}

Hasil nilai korelasi antar variabel yaitu antara $\mathrm{X}_{1}$ dan $\mathrm{Y}$ sebesar 0,515 yang berada pada taraf signifikansi 0,000 artinya terdapat hubungan langsung yang signifikan antara inovasi kepala sekolah dengan kinerja guru.

Miles (dalam Soemanto, 1980) menyatakan bahwa inovasi adalah macam-macam perubahan. Inovasi sebagai perubahan disengaja, baru, khusus untuk mencapai tujuan-tujuan sistem. Dalam melakukan inovasi dibutuhkan peran yang sangat penting kepala sekolah. Kepala sekolah adalah guru yang mendapat tambahan tugas sebagai kepala sekolah. Sebagai seorang kepala sekolah dituntut untuk memikirkan perkembangan dan kemajuan sekolah, sesuai dengan tuntutan dan perkembangan masyarakat. Kepala sekolah juga merupakan top leader dari suatu lembaga pendidikan. Kebijakan yang diputuskan merupakan hal yang strategis dalam keberhasilan sekolah. Kepala sekolah seharusnya orang yang memiliki kecerdasan, kekreatifan, visi, dan tujuan ke depan dalam menatap realitas masyarakat yang semakin global. Gorton (1976) menyatakan bahwa kepala sekolah adalah agen pembaharu, sangat penting dalam inovasi pendidikan. Kepala sekolah apabila membawa perubahan atau inovasi tidak hanya untuk kemajuan sekolah tetapi juga untuk kemajuan kinerja guru.

Keberhasilan seorang guru dapat dilihat dari kriteria-kriteria yang ada dan yang dicapai secara keseluruhan. Jika kriteria telah tercapai, berarti pekerjaan seseorang telah dianggap memiliki kualitas kerja yang baik. Kinerja guru adalah hasil kerja dari serangkaian kemampuan yang dimiliki oleh seorang yang berprofesi guru. Inovasi yang dilakukan oleh kepala sekolah mempunyai dampak terhadap kinerja guru.

Hasil nilai korelasi antar variabel yaitu antara $\mathrm{X}_{1}$ dan $\mathrm{X}_{3}$ sebesar 0,415 berada pada taraf signifikansi 0,000 artinya terdapat hubungan langsung yang signifikan antara inovasi kepala sekolah dengan motivasi kerja.

Mulyasa (2007) menyatakan bahwa kepala sekolah sebagai innovator akan tercermin dari caracara ia melakukan pekerjaannya secara konstruktif, kreatif, delegatif, integratif, rasional, dan objektif, pragmatis, keteladanan, disiplin, serta adaptabel, dan fleksibel. Konstruktif dimaksudkan bahwa dalam me- 
ningkatkan profesionalisme tenaga kependidikan di sekolah, kepala sekolah harus berusaha mendorong dan membina setiap tenaga kependidikan agar dapat berkembang secara optimal dalam melakukan tugastugas yang diembankan kepada masing-masing tenaga kependidikan.

Seorang kepala sekolah mendorong atau memberikan motivasi kepada guru atau tenaga kependidikan dan merupakan wujud kepala sekolah sebagai inovator atau inovasi yang dilakukan oleh kepala sekolah.

Hasil nilai korelasi antar variabel yaitu antara $\mathrm{X}_{2}$ dan $\mathrm{Y}$ sebesar 0,455 yang berada pada taraf signifikansi 0,000 artinya terdapat hubungan langsung yang signifikan antara kelengkapan sarana prasarana sekolah dengan kinerja guru. Barnawi dan Arifin (2012) memaparkan bahwa kinerja adalah tingkat keberhasilan seseorang atau kelompok dalam melaksanakan tugas sesuai dengan tanggung jawab dan wewenangnya berdasarkan standar kinerja yang telah ditetapkan selama periode tertentu dalam rangka mencapai tujuan organisasi.

Kelengkapan sarana prasarana sekolah berdampak pada kinerja seorang guru. Salah satu faktor yang mempengaruhi kinerja guru yaitu faktor dari luar diri sendiri (ekstern) diantaranya yaitu sarana dan prasarana sekolah. Adanya sarana dan prasarana yang memadai dapat membantu guru dalam meningkatkan kinerjanya terutama dalam proses belajar mengajar. Peningkatan dan perbaikan pendidikan dilakukan secara bertahap. Dinamika guru dalam pengembangan program pembelajaran tidak akan bermakna bagi perbaikan proses dan hasil belajar siswa, jika manajemen sekolah tidak memberi peluang tumbuh dan berkembangnya kreatifitas guru.

Penambahan sumber belajar berupa perpustakaan dan laboratorium tidak akan bermakna jika manajemen sekolah tidak memberikan perhatian serius dalam mengoptimalkan pemanfaatan sumber belajar tersebut dalam proses belajar mengajar. Tersedianya sarana dan prasarana sekolah yang memadai merupakan salah satu faktor penunjang dalam peningkatan kinerja guru.

Hasil nilai antara variabel $X_{2}$ dan $X_{3}$ sebesar 0,382 yang berada pada taraf signifikansi 0,001 artinya terdapat hubungan langsung yang signifikan antara kelengkapan sarana prasarana sekolah dengan motivasi kerja.

Menurut Maslow (dalam Robbins, 2006) menyatakan bahwa di dalam diri semua manusia terdapat lima jenjang kebutuhan, yaitu: (1) psikologis: antara lain rasa lapar, haus, perlindungan (pakaian dan rumah), seks, dan kebutuhan jasmani lain; (2) kea- manan: antara lain keselamatan dan perlindungan terhadap kerugian fisik dan emosional; (3) sosial: mencakup kasih sayang, rasa memiliki, diterima baik, dan persahabatan; (4) penghargaan: mencakup faktor penghormatan diri seperti harga diri, otonomi, dan prestasi; serta faktor penghormatan dari luar seperti misalnya status, pengakuan, dan perhatian; (5) aktualisasi diri: dorongan untuk menjadi seseorang/sesuatu sesuai ambisinya yang mencakup pertumbuhan, pencapaian potensi, dan pemenuhan kebutuhan diri.

Berdasarkan teori yang diungkapkan oleh Maslow pada jenjang kebutuhan yang pertama yaitu psikologis atau kebutuhan jasmani, dalam lingkup sekolah maka dapat diartikan bahwa manusia membutuhkan sarana prasarana misalnya pakaian sekolah, ruang kelas, buku pelajaran, dan sebagainya. Secara langsung terdapat hubungan antara kelengkapan sarana prasarana sekolah dengan motivasi kerja guru.

Hasil nilai korelasi antara variabel $\mathrm{X}_{3}$ dengan $\mathrm{Y}$ yaitu sebesar 0,604 yang berada pada taraf signifikansi 0,000 artinya terdapat hubungan langsung yang signifikan antara kelengkapan sarana prasarana sekolah dengan kinerja guru.

Hal ini diperkuat oleh teori yang diungkapkan oleh Victor Vroom. Istilah lain yang lebih praktis yaitu teori pengharapan, karyawan dimotivasi untuk melakukan upaya lebih keras bila ia meyakini upaya itu akan menghasilkan penilaian kinerja yang baik. Penilaian yang baik akan mendorong imbalan organisasi seperti bonus, kenaikan gaji, atau promosi. Imbalan akan memenuhi sasaran pribadi karyawan itu.

Menurut Robbins (2006), kinerja sebagai fungsi interaksi antara kemampuan atau ability (A), motivasi atau motivation (M) dan kesempatan atau opportunity $(\mathrm{O})$, yaitu kinerja $=f(\mathrm{~A} \times \mathrm{M} \times \mathrm{O})$. Artinya: kinerja merupakan fungsi dari kemampuan, motivasi dan kesempatan. Berdasarkan teori tersebut, yang menentukan kinerja guru salah satu faktornya adalah motivasi. Motivasi yang tinggi akan meningkatkan kinerja guru.

Hasil nilai korelasi antar variabel yaitu $\mathrm{X}_{1} \mathrm{X}_{2}$, $\mathrm{X}_{3}$, dan $\mathrm{Y}$ sebesar 0,604 yang berada pada taraf signifikansi 0,000 artinya terdapat hubungan langsung yang signifikan antara inovasi kepala sekolah, kelengkapan sarana prasarana sekolah, motivasi kerja, dengan kinerja guru.

Menurut Miles (dalam Soemanto, 1980) menyatakan bahwa inovasi adalah macam-macam perubahan. Inovasi sebagai perubahan disengaja, baru, khusus untuk mencapai tujuan-tujuan sistem. Kepala sekolah adalah guru yang mendapat tambahan tugas sebagai kepala sekolah. Sebagai seorang kepala sekolah, di- 
tuntut untuk memikirkan perkembangan dan kemajuan sekolah, sesuai dengan tuntutan dan perkembangan masyarakat. Dalam melakukan inovasi, kepala sekolah melaksanakannya sesuai dengan perkembangan atau pembaharuan yang ada di lingkungan sekolah atau sesuai dengan prosedur yang berlaku.

Kelengkapan sarana dan prasarana sekolah juga dilaksanakan sesuai dengan standar dan proses yang telah ditentukan. Barnawi dan Arifin (2012) mengungkapkan bahwa manajemen sarana dan prasarana adalah segenap proses pengadaan dan pendayagunaan sarana dan prasarana agar mendukung tercapainya tujuan pendidikan secara tepat guna dan tepat sasaran. Apabila dalam proses sarana dan prasarana sekolah dapat dilaksanakan sesuai dengan ketentuan, maka kelengkapan sarana dan prasarana sekolah dapat tercapai sesuai dengan yang diharapkan.

Sarana dan prasarana sekolah sangat menunjang pekerjaan guru. Hal ini dapat dibandingkan antara guru yang dilengkapi sarana dan prasarana yang memadai dengan guru yang tidak dilengkapi sarana dan prasarana yang memadai. Guru yang dilengkapi dengan sarana dan prasarana yang memadai akan menunjukkan kinerja yang lebih baik daripada guru yang tidak dilengkapi dengan sarana dan prasarana yang memadai. Kualitas sarana dan prasarana hendaknya mengikuti perkembangan teknologi yang lebih mutakhir. Sarana dan prasarana yang digunakan adalah sarana dan prasarana yang modern yang mengikuti perkembangan ilmu pengetahuan, teknologi, dan seni.

Motivasi juga memiliki peran yang sangat penting dalam meningkatkan kinerja seseorang. Sejalan dengan yang diungkapkan oleh Maslow tentang teori kebutuhan yaitu 1) psikologis: antara lain rasa lapar, haus, perlindungan (pakaian dan perumahan), seks, dan kebutuhan jasmani lain, 2) keamanan: antara lain keselamatan dan perlindungan terhadap kerugian fisik dan emosional, 3) sosial: mencakup kasih sayang, rasa memiliki, diterima baik, dan persahabatan, 4) penghargaan: mencakup faktor penghormatan diri seperti harga diri, otonomi, dan prestasi; serta faktor penghormatan dari luar seperti misalnya status, pengakuan, dan perhatian, 5) aktualisasi diri: dorongan untuk menjadi seseorang/sesuatu sesuai ambisinya yang mencakup pertumbuhan, pencapaian potensi, dan pemenuhan kebutuhan diri.

Kinerja guru sangat ditentukan dengan adanya motivasi kerja, kelengkapan sarana dan prasarana sekolah serta inovasi kepala sekolah.

Hasil nilai korelasi antar variabel yaitu $\mathrm{X}_{1}, \mathrm{X}_{3}$, dan Y sebesar 0,243 yang berada pada taraf signifikansi 0,000 artinya terdapat hubungan tidak langsung yang signifikan antara inovasi kepala sekolah, motivasi kerja, dengan kinerja guru.

Inovasi dilakukan kepala sekolah dalam berbagai bidang dan sangat menentukan kinerja seorang guru. Baik tidaknya kinerja seorang guru juga dapat ditentukan melalui inovasi pengelolaan guru yang pada akhirnya dapat menentukan kinerja guru.

Menurut Ibrahim (1998), proses inovasi pengelolaan guru merupakan salah satu kunci keberhasilan (key to succesfullnes) sekolah, sebab guru merupakan salah satu komponen pendidikan yang memengaruhi keberhasilan dalam institusi pendidikan. Profesionalisme guru diperlukan dibidang pengetahuan, sikap, dan keterampilan. Profesionalisasi guru diperlukan untuk melangsungkan proses inovasi di sekolah. Kecerdikan, kekreatifan, dan memiliki etos dan komitmen yang tinggi tumbuh berkembang secara personal profesional merupakan sikap inovatif yang dibutuhkan pula untuk melaksanakan inovasi pendidikan sekolah.

Mangkunegara (2006) mengungkapkan bahwa faktor yang mempengaruhi kinerja guru adalah faktor kemampuan (ability) dan faktor motivasi (motivation). Motivasi terbentuk dari sikap seorang guru dalam menghadapi situasi kerja. Motivasi merupakan kondisi yang menggerakkan seseorang yang terarah untuk mencapai tujuan pendidikan.

McClelland (dalam Robbins, 2006) berpendapat bahwa ada hubungan yang positif antara motif berprestasi dengan pencapaian kinerja. Guru sebagai pendidik memiliki tugas dan tanggung jawab yang berat. Guru menyadari bahwa dalam mengerjakan tugasnya dilakukan dengan sungguh-sungguh, bertanggung jawab, ikhlas dan tidak asal-asalan, sehingga siswa dapat dengan mudah menerima apa saja yang disampaikan oleh gurunya. Guru akan memiliki tingkat kinerja yang tinggi jika ini tercapai. Dapat dinyatakan bahwa terdapat hubungan tidak langsung antara inovasi kepala sekolah, motivasi kerja, dengan kinerja guru SMA Negeri di Kabupaten Sumbawa Besar.

Hasil nilai korelasi antar variabel yaitu $\mathrm{X}_{2}, \mathrm{X}_{3}$, dan Y sebesar 0,211 berada pada taraf signifikansi 0,000 artinya terdapat hubungan tidak langsung yang signifikan antara kelengkapan sarana prasarana sekolah, motivasi kerja, dengan kinerja guru.

Menurut Mangkunegara (2000) sarana prasarana merupakan salah satu faktor yang mendukung kinerja guru. Tersedianya sarana dan prasarana yang memadai membantu guru dalam meningkatkan kinerjanya terutama kinerja dalam proses mengajar mengajar. Peningkatan dan perbaikan pendidikan harus 
dilakukan secara bertahap. Dinamika guru dalam pengembangan program pembelajaran tidak akan bermakna bagi perbaikan proses dan hasil belajar siswa, jika manajemen sekolahnya tidak memberi peluang tumbuh dan berkembangnya kreatifitas guru.

Motivasi juga merupakan salah satu faktor yang mempengaruhi kinerja guru. Motivasi terbentuk dari sikap seorang guru dalam menghadapi situasi kerja. Motivasi merupakan kondisi yang menggerakkan seseorang yang terarah untuk mencapai tujuan pendidikan. Dapat disimpulkan bahwa ada hubungan tidak langsung antara kelengkapan sarana prasarana sekolah, motivasi kerja, dengan kinerja guru SMA Negeri di Kabupaten Sumbawa Besar.

\section{SIMPULANDAN SARAN}

\section{Simpulan}

Berdasarkan hasil penelitian menunjukkan bahwa: (1) terdapat hubungan langsung antara inovasi kepala sekolah dengan kinerja guru, (2) terdapat hubungan langsung antara inovasi kepala sekolah dengan motivasi kerja guru, (3) terdapat hubungan langsung antara kelengkapan sarana prasarana dengan kinerja guru, (4) terdapat hubungan langsung antara kelengkapan sarana prasarana dengan motivasi kerja guru, (5) terdapat hubungan langsung antara motivasi kerja dengan kinerja guru, (6) terdapat hubungan langsung antara inovasi kepala sekolah, kelengkapan sarana prasarana sekolah, motivasi kerja, dengan kinerja guru, (7) terdapat hubungan tidak langsung antara inovasi kepala sekolah, motivasi kerja, dengan kinerja guru, dan (8) terdapat hubungan tidak langsung antara kelengkapan sarana prasarana sekolah, motivasi kerja, dengan kinerja guru SMA Negeri di Kabupaten Sumbawa Besar.

\section{Saran}

Beberapa saran yang dikemukakan adalah sebagai berikut. (1) Kepala Dinas dan Pengawas Pendidikan di Kabupaten Sumbawa Besar, hendaknya memberikan masukan atau arahan secara kontinyu kepada para kepala sekolah atau guru sehingga dapat memotivasi atau meningkatkan kinerja guru SMA Negeri di Kabupaten Sumbawa Besar. (2) Kepala SMA Negeri di Kabupaten Sumbawa Besar, disarankan agar dalam melakukan inovasi di sekolah hendaknya dilaksanakan sesuai dengan pembaruan yang ada sehingga menimbulkan perubahan yang pada akhirnya terciptanya inovasi baik dalam bidang sarana prasarana sekolah atau dalam bidang lainnya guna meningkatkan kinerja guru SMA Negeri di Kabupaten Sumbawa Besar. (3) Guru SMA Negeri di Kabupaten Sumbawa Besar, para guru hendaknya tetap saling memberikan motivasi satu sama lain guna tercapainya kinerja yang baik antar sesama rekan kerja serta dapat memelihara kelengkapan sarana dan prasarana sekolah untuk meningkatkan kinerja guru.

\section{DAFTAR RUJUKAN}

Barnawi dan Arifin, M. 2012. Kinerja Guru Profesional. Jogjakarta: Ar-Ruz Media.

Barnawi dan Arifin, M. 2012. Manajemen Sarana dan Prasarana Sekolah. Jogjakarta: Ar-Ruz Media.

Direktorat Tenaga Kependidikan Direktorat Jenderal Peningkatan Mutu Pendidik dan Tenaga Kependidikan Departemen Pendidikan Nasional. 2007. Manajamen Sarana dan Prasarana Pendidikan Persekolahan Berbasis Sekolah, (Online), (http:/ /www.dit-plp.go/id), diakses 7 Desember 2009.

Ibrahim. 1998. Inovasi Pendidikan. Jakarta: Depdikbud Dikti, Proyek Pengembangan Tenaga Kependidikan.

Mangkunegara, A.A.A.P. 2006. Evaluasi Kinerja SDM. Bandung: PT Refika Aditema.

Mangkunegara, A.A.A.P. 2007. Manajemen Sumber Daya Manusia Perusahaan. Bandung: PT Remaja Rosdakarya.

Mulyasa, E. 2007. Menjadi Kepala Sekolah Profesional. Bandung: PT Remaja Rosdakarya.

Robbins, S.P. 2006. Perilaku Organisasi (Edisi Kesepuluh). Jakarta: PT. Macanan Jaya Cemerlang.

Soemanto, W. 1980. Petunjuk untuk Pembinaan Pendidikan. Surabaya: Usaha Nasional.

Suharsono dan Retnoningsih, A. 2011. Kamus Besar Bahasa Indonesia (Edisi Lux). Semarang: Widya Karya. 